Note

\title{
ATTRACTANTS IN PLANT PROTEIN-BASED DIETS FOR THE CARNIVOROUS LARGEMOUTH BASS Micropterus salmoides
}

\author{
Ana Maria Barretto de Menezes Sampaio de Oliveira ${ }^{1}$; José Eurico Possebon Cyrino ${ }^{2 *}$ \\ ${ }^{1}$ USP/ESALQ - Programa de Pós-Graduação em Ciência Animal e Pastagens. \\ ${ }^{2}$ USP/ESALQ - Depto. de Zootecnia, C.P. 09 - 13418-900 - Piracicaba, SP - Brasil. \\ *Corresponding author <jepcyrin@esalq.usp.br>
}

\begin{abstract}
Adding attractants can improve acceptability of artificial diets by carnivorous fish fry and fingerlings, increasing intake of unpalatable feeds and improving growth rate, while reducing feeding time and feeding wastes. This study aimed to evaluate the effects of levels of inclusion of different attractants in plant protein-based diets on the performance of largemouth bass Micropterus salmoides. Nine hundred juvenile largemouth bass $(26.54 \pm 1.53 \mathrm{~g}$ ) conditioned to accept dry, artificial feed were stocked in 60,90 -L polyethylene tanks (15 fish per group) in a completely randomized design trial $(n=3)$. Fish were fed two daily meals $a d$ libitum at $7 \mathrm{~h} 00$ and $17 \mathrm{~h} 00$, for 13 days, with a diet ( $100 \%$ plant protein source) containing either soluble fish protein - SFP $\left(0.5,1.0,1.5,2.0,2.5\right.$, and 3.0\%); Fisharon $^{\text {TM }}$ - FA $(0.02,0.04,0.06,0.08,0.10,0.12 \%)$; fish silage - FS (1.0, 2.0, 3.0, 4.0, 5.0, and 6.0\%); a positive control diet - pCD (10\% fish meal) and a negative control diet - nCD (basal diet without attractants). DL-methionine (98\%) and L-lysine (80\%) were added automatically by the formulation software to adjust available amino-acid profile of diets. Recorded performance data were: final weight, feed intake, weight gain and feed conversion ratio. Fish fed diet FA0.02 presented the best growth rate, best weight gain and best feed conversion ratio. Fish fed diets containing FS as attractant presented the poorest performance.
\end{abstract}

Key words: feeding attractants, palatability, carnivorous fish

\section{ATRATIVOS ALIMENTARES EM DIETAS DE BASE PROTÉICA VEGETAL PARA O "BLACK BASS" Micropterus salmoides}

\begin{abstract}
RESUMO: A adição de estimulantes pode melhorar a aceitabilidade de dietas artificiais por pós-larvas e alevinos de peixes carnívoros, aumentando a ingestão de alimentos não palatáveis e a taxa de crescimento, reduzindo o tempo de alimentação e perdas alimentares. Investigou-se o uso de atrativos alimentares em dietas formuladas exclusivamente à base de proteína de origem vegetal (PV), e seus efeitos no desempenho de alevinos do carnívoro "black bass", Micropterus salmoides, condicionados a aceitar ração seca. Novecentos juvenis $(26,54 \pm 1,53 \mathrm{~g})$ foram estocados em 60 aquários de polietileno de $90 \mathrm{~L}$ ( 15 peixes por aquário), em delineamento experimental totalmente ao acaso $(\mathrm{n}=3)$, e alimentados ad libitum em duas refeições diárias (7h00 e 17h00), durante 13 dias, com uma dieta basal (100\% PV) contendo seis níveis de proteína solúvel de peixe - PSP $\left(0,5,1,0,1,5,2,0,2,5\right.$ e 3,0\%); Fisharom ${ }^{\circledR}-$ FA $(0,02,0,04,0,06,0,08,0,10$ e $0,12 \%)$; silagem de peixe - SP (1,0, 2,0, 3,0, 4,0, 5,0 e 6,0\%); um controle positivo (10\% de farinha de peixe) e um controle negativo (dieta basal sem atrativos). Os peixes alimentados com a dieta contendo FA 0,02\% apresentaram melhor taxa de crescimento, ganho de peso e conversão alimentar. Os peixes alimentados com dietas contendo SP como atrativo apresentaram os piores resultados de desempenho.

Palavras-chave: estimulantes, palatabilidade, peixes carnívoros
\end{abstract}

\section{INTRODUCTION}

Production of carnivorous fish represents $6 \%$ of the total aquaculture production in the world (FAO, 2002). The farming and husbandry of carnivorous fish demand the adoption of intensively managed production systems where feed management practices play an important role and requires serious research efforts for the generation of appropriate technology (Cyrino \& Kubitza, 2003).
The largemouth bass Micropterus salmoides Lacepéde 1802 (Perciformes: Centrarchidae) is native of lakes and small rivers of North America. It is also found in Mexico and some European countries, and was introduced in the State of Minas Gerais in 1924 (Godoy, 1954) from where it quickly disseminated through areas of temperate climate in South East and South Brazil, and is today extensively managed as a sport fish. However, because fishing pressure is high and release 
of sport catch is not a common practice, largemouth bass populations in dams and reservoirs are in constant danger.

Therefore, there is an increasing need for commercial, intensive farming of largemouth bass for restocking purposes. In addition, largemouth bass can also be raised as food fish. Intensive production of advanced juveniles of largemouth bass fed commercial, dry diets in static ponds with emergency aeration can yield $7,200 \mathrm{~kg} \mathrm{ha}^{-1}$ in 117 to 153 days, with feed conversion ratios ranging from 0.97 to 1.14 (Kubitza, 1995; Kubitza \& Lovshin, 1997).

Supplementation of artificial, dry diets with attractants (feeding stimulants) can increase acceptability and, consequently, the consumption of low palatability diets by fry and fingerlings, which can increase growth rate and productivity. This practice can also reduce feeding time and feed waste, while improving water quality and environmental safety.

Food flavor is mediated chemically by substances inherent to the food, and it is affected by the chemosensitivity of the species (Adams et al., 1988). Therefore, mixtures of attractants are more effective than individual components (Kubitza, 1995). L-amino acids are known to mediate alimentary responses of fish, particularly the neutral amino acids, and organic, aminated bases and nucleotides are also involved in the alimentary response of fish (Hughes, 1991; Kubitza, 1995).

This work evaluates whether the use of attractants in plant protein-based diets will positively affect ingestion and nutritional performance of juvenile, largemouth bass. Applying this technique to alimentary adaptation of largemouth bass or any other carnivorous sport or food fish, as a refinement of the production strategies for all these prized, highly valued species, can open new perspectives to the emerging industry of Brazilian fish culture.

\section{MATERIAL AND METHODS}

Trials were set up in indoor facilities in Piracicaba, SP, Brazil ( $22^{\circ} 42^{\prime} 30^{\prime}$ 'S, $47^{\circ} 38^{\prime} 00^{\prime}$ 'W), in a closed water recycling system with controlled temperature $\left(27.0 \pm 1.07^{\circ} \mathrm{C}\right)$ and photoperiod (14L:10D). Water quality parameters were monitored daily.

Chemical analyses of feedstuffs, diets, feces and fish carcasses were made on a dry matter basis $(n=3)$. Crude protein was analyzed by the Kjeldahl method ( $\mathrm{N} \mathrm{x} \mathrm{6.25);} \mathrm{lipids} \mathrm{were} \mathrm{analyzed} \mathrm{by} \mathrm{the} \mathrm{Soxhlet} \mathrm{method}$ (petroleum ether extract), and crude fiber by the Weende method. The oxidimetric method was used to analyze calcium, and phosphorus was analyzed by colorimetry after acid digestion and mineralization of organic matter. Energy was estimated with an adiabatic, bomb calorimetry pump and benzoic acid standard.

Feed ingredients were ground through a $1.0-\mathrm{mm}$ sieve, homogenized and mixed, moistened with distilled water $(2: 1 ; \mathrm{w}: \mathrm{v})$ and pelleted $(2.0 \mathrm{~mm})$ in a mincer. Prepared rations were dried in a forced ventilation oven at $55^{\circ} \mathrm{C}$ for 24 hours, and stored in hermetically sealed plastic bags at $-4^{\circ} \mathrm{C}$. The trial was carried out for 13 days (Papatryphon \& Soares Jr., 2000b). Six levels of three attractants were tested (Table 1): fish silage - FS (1.0, 2.0, 3.0, 4.0, 5.0 and 6.0\%), Fisharon ${ }^{\mathrm{TM}}$ - FA (0.02, 0.04, 0.06, $0.08,0.10,0.12 \%)$, and fish soluble protein - FSP $(0.5$, $1.0,1.5,2.0,2.5,3.0 \%)$. A positive control diet - pCD (10\% fish meal) and a negative control diet - nCD (basal diet without stimulant) were also tested. Synthetic amino acids DL-methionine (98\%) and L-lysine (80\%) were added automatically by the formulation software matrix (Brill Formulations ${ }^{\mathrm{TM}}$ ) to adjust available dietary amino acid balance (Table 2).

Nine hundred juvenile largemouth bass (26.54 \pm $1.53 \mathrm{~g}$ ), conditioned to accept dry, artificial feed, were subjected to 24-hours of fasting, anesthetized in benzocaine solution $\left(100 \mathrm{mg} \mathrm{L}^{-1}\right)$, weighed on a semi-analytical scale to the nearest $0.001 \mathrm{~g}$, and randomly assigned to $90-\mathrm{L}$ polyethylene tanks (15 fish per tank), in a completely randomized design $(n=3)$. Average initial weight of fish was uniform, and did not present differences among treatments.

Fish were fed daily meals (7h00 and $17 \mathrm{~h} 00)$ to satiation, with isonitrogenous ( $40 \%$ crude protein) and isocaloric (3.500 kcal de DE kg $\mathrm{kg}^{-1}$ ) diets (Table 3). At the end of the assay, fish were anesthetized and total final weight of fish was recorded. Average feed intake, weight gain and feed conversion ratio were considered as performance parameters and subjected to statistical analysis using SAS (V8.2, SAS Institute Inc. Cary, North Carolina, USA) at $5 \%$.

\section{RESULTS AND DISCUSSION}

The average values for water quality parameters were: $\mathrm{pH} 7.5$; temperature $27.0 \pm 1.07^{\circ} \mathrm{C}$; DO $6.8 \pm 0.7$ $\mathrm{mg} \mathrm{L}^{-1}$; and total alkalinity $55 \mathrm{mg} \mathrm{L}^{-1}$ equivalent $\mathrm{CaCO}_{3}$.

Table 1 - Nutritional composition of feed attractants used in the experimental diets for juvenile largemouth bass.

\begin{tabular}{lrcc}
\hline \multirow{2}{*}{$\begin{array}{l}\text { Nutrient } \\
\text { composition }\end{array}$} & \multicolumn{3}{c}{ Attractant } \\
\cline { 2 - 4 } Protein, \% & Fisharon ${ }^{\mathrm{TM}}$ & Fish Silage Soluble fish protein \\
Lipid, \% & 0.93 & 58.71 & 80.73 \\
Crude fiber, \% & 99.26 & 12.06 & 4.96 \\
Ash, \% & 0.09 & 0.28 \\
Gross energy, & $8,970.00$ & $4,587.00$ & $4,997.00$ \\
kcal kg & & 14.69 & 0.11 \\
Calcium, \% & & 3.16 & 0.36 \\
Phosphorus, \% & & 2.29 & $0.1 \%$ \\
\hline
\end{tabular}

$* 12 \%$ cod liver oil; $0.3 \%$ fatty acids; $0.4 \%$ humic oil; $0.1 \%$ natural essential oil; $87 \%$ corn oil; $0.2 \%$ BHT 
Table 2 - Ingredient composition of the experimental diets for juvenile largemouth bass.

\begin{tabular}{|c|c|c|c|c|c|c|}
\hline \multirow{2}{*}{ Ingredient } & \multicolumn{6}{|c|}{ Soluble fish protein } \\
\hline & SFP $0.5 \%$ & SFP $1.0 \%$ & SFP $1.5 \%$ & SFP $2.0 \%$ & SFP $2.5 \%$ & SFP $3.0 \%$ \\
\hline Corn meal & 8.80 & 8.94 & 9.08 & 9.22 & 9.36 & 9.50 \\
\hline Corn gluten meal & 27.20 & 26.47 & 25.74 & 25.02 & 24.29 & 23.56 \\
\hline Wheat meal & 15.00 & 15.00 & 15.00 & 15.00 & 15.00 & 15.00 \\
\hline Soybean oil & 5.92 & 5.91 & 5.90 & 5.88 & 5.87 & 5.86 \\
\hline Soybean meal & 39.32 & 39.44 & 39.57 & 39.69 & 39.81 & 39.94 \\
\hline Fish meal & 1.48 & 1.48 & 1.48 & 1.49 & 1.49 & 1.50 \\
\hline Di-base calcium phosphate & 0.23 & 0.23 & 0.23 & 0.23 & 0.23 & 0.23 \\
\hline Soluble fish protein & 0.5 & 1.0 & 1.5 & 2.0 & 2.5 & 3.0 \\
\hline DL-Methionine (98\%) & 0.75 & 0.72 & 0.70 & 0.67 & 0.64 & 0.62 \\
\hline \multirow[t]{2}{*}{ L-Lysine $(80 \%)$} & 0.80 & 0.80 & 0.80 & 0.80 & 0.80 & 0.80 \\
\hline & \multicolumn{6}{|c|}{ Fisharon $^{\mathrm{TM}}$} \\
\hline Ingredient & FA $0.02 \%$ & FA $0.04 \%$ & FA $0.06 \%$ & FA $0.08 \%$ & FA $0.10 \%$ & FA $0.12 \%$ \\
\hline Corn meal & 8.66 & 8.66 & 8.66 & 8.66 & 8.66 & 8.66 \\
\hline Corn gluten meal & 27.93 & 27.93 & 27.93 & 27.93 & 27.93 & 27.92 \\
\hline Wheat meal & 15.00 & 15.00 & 15.00 & 15.00 & 15.00 & 15.00 \\
\hline Soybean oil & 5.92 & 5.90 & 5.88 & 5.86 & 5.83 & 5.81 \\
\hline Soybean meal & 39.20 & 39.20 & 39.20 & 39.20 & 39.20 & 39.20 \\
\hline Fish meal & 1.47 & 1.47 & 1.47 & 1.47 & 1.47 & 1.47 \\
\hline Di-base calcium phosphate & 0.23 & 0.23 & 0.23 & 0.23 & 0.23 & 0.23 \\
\hline Fisharon $^{\circledast}$ & 0.02 & 0.04 & 0.06 & 0.08 & 0.10 & 0.12 \\
\hline DL-Methionine (98\%) & 0.78 & 0.78 & 0.78 & 0.78 & 0.78 & 0.78 \\
\hline \multirow[t]{2}{*}{ L-Lysine $(80 \%)$} & 0.80 & 0.80 & 0.80 & 0.80 & 0.80 & 0.80 \\
\hline & \multicolumn{6}{|c|}{ Fish Silage } \\
\hline Ingredient & FS $1.0 \%$ & FS $2.0 \%$ & FS $3.0 \%$ & FS $4.0 \%$ & FS $5.0 \%$ & FS \%6.0 \\
\hline Corn meal & 8.44 & 8.46 & 8.47 & 8.48 & 8.49 & 8.50 \\
\hline Corn gluten meal & 29.59 & 29.73 & 29.88 & 30.02 & 30.17 & 30.33 \\
\hline Wheat meal & 15.00 & 15.00 & 15.00 & 15.00 & 15.00 & 15.00 \\
\hline Soybean oil & 5.85 & 5.75 & 5.66 & 5.57 & 5.47 & 5.37 \\
\hline Soybean meal & 35.87 & 34.75 & 33.63 & 32.51 & 31.39 & 30.27 \\
\hline Fish meal & 2.34 & 2.35 & 2.37 & 2.38 & 2.39 & 2.40 \\
\hline Di-base calcium phosphate & 0.23 & 0.23 & 0.24 & 0.24 & 0.25 & 0.25 \\
\hline Fish Silage & 1.0 & 2.0 & 3.0 & 4.0 & 5.0 & 6.0 \\
\hline DL-Methionine (98\%) & 0.88 & 0.92 & 0.96 & 1.00 & 1.04 & 1.08 \\
\hline \multirow[t]{2}{*}{ L-Lysine $(80 \%)$} & 0.80 & 0.80 & 0.80 & 0.80 & 0.80 & 0.80 \\
\hline & \multicolumn{6}{|c|}{ Diet } \\
\hline Ingredient & \multicolumn{3}{|c|}{ Positive control - PC 10\% FP } & \multicolumn{3}{|c|}{ Negative control - NC $100 \% \mathrm{PV}$} \\
\hline Corn meal & \multicolumn{3}{|c|}{10.64} & \multicolumn{3}{|c|}{8.66} \\
\hline Corn gluten meal & \multirow{2}{*}{\multicolumn{3}{|c|}{18.05}} & \multicolumn{3}{|c|}{27.93} \\
\hline Wheat meal & \multirow{2}{*}{\multicolumn{3}{|c|}{$\begin{array}{r}15.00 \\
4.90\end{array}$}} & \multicolumn{3}{|c|}{15.00} \\
\hline Soybean oil & & & & \multicolumn{3}{|c|}{5.94} \\
\hline Soybean meal & \multicolumn{3}{|c|}{39.07} & \multicolumn{3}{|c|}{39.19} \\
\hline Fish meal & \multicolumn{3}{|c|}{10.00} & & 0.00 & \\
\hline Di-base calcium phosphate & \multicolumn{3}{|c|}{1.11} & & 1.47 & \\
\hline DL-Methionine (98\%) & & 0.19 & & & 0.23 & \\
\hline L-Lysine (80\%) & & 0.24 & & & 0.78 & \\
\hline Mineral and vitamin mix & & 0.80 & & & 0.80 & \\
\hline $\begin{array}{l}\text { Selected, particular chemical } \\
\text { lipids } 13.22 \text {; acidity } 5.53 \text {; - soy } \\
\text { wheat meal: CP } 17.12 \\
\text { bitamin and mineral supplen } \\
\text { vitamin C } 320 \mathrm{mg} \text {; thiamine } 10 \\
\text { acid } 2 \mathrm{mg} \text {; biotin } 900 \mathrm{mcg} \text {; ch }\end{array}$ & $\begin{array}{l}\text { on of feedstuf } \\
\text { al: CP } 51.40 \text {; } \\
\text { (per } \mathrm{kg} \text { of fee } \\
\text { flavin } 20 \mathrm{mg} \text {; }\end{array}$ & $\begin{array}{l}\text { g } 100 \mathrm{~g}^{-1} \mathrm{DM} \\
\text { ds } 6.71 ; \text { urea } \\
\text { vitamin A } 8 \text {, } \\
\text { ridoxine } 15 \mathrm{n}\end{array}$ & $\begin{array}{l}\text { corn: crude } 1 \\
.03 \text {; solubili }\end{array}$ & $\begin{array}{l}\text { in (CP) } 10.4 \\
0.93 \text {; - corn } \\
4,000 \text { UI; v } \\
\text { icg; panthote }\end{array}$ & $\begin{array}{l}\text { ids } 4.21 \text {; - fi } \\
\text { en meal: CP } \\
\text { in E } 160 \mathrm{UI}\end{array}$ & $\begin{array}{l}\text { neal: CP } 71.5 \\
\text { 24; lipids } 3.6\end{array}$ \\
\hline
\end{tabular}

Variations were within the tolerable range for the species (Brune \& Tomasso, 1991). There were no differences among treatments for any of the analyzed performance parameters - final weight, feed intake, weight gain or feed conversion ratio (Table 4). However, a graphic analysis showed that best performance parameters were associated with the treatment containing $0.02 \%$ Fisharon $^{\mathrm{TM}}$ (Figures $1,2,3)$. 
Table 3 - Nutritional composition of experimental diets.

\begin{tabular}{lcccccccccc}
\hline \multirow{2}{*}{ Composition } & \multicolumn{10}{c}{ Diet } \\
\cline { 2 - 11 } & SFP 0.5 & SFP 1.0 & SFP 1.5 & SFP 2.0 & SFP 2.5 & SFP 3.0 & FA 0.02 & FA 0.04 & FA 0.06 & FA 0.08 \\
\hline Protein, \% & 39.54 & 37.68 & 39.53 & 39.68 & 38.50 & 39.75 & 38.17 & 39.20 & 39.15 & 36.71 \\
Lipid, \% & 8.51 & 9.69 & 9.92 & 10.26 & 10.43 & 9.63 & 10.39 & 10.36 & 10.05 & 9.99 \\
Ash, \% & 5.52 & 5.44 & 5.52 & 5.54 & 5.39 & 5.38 & 5.52 & 5.52 & 5.37 & 5.51 \\
Crude fiber, \% & 4.54 & 5.16 & 4.02 & 4.64 & 3.74 & 3.80 & 4.49 & 4.64 & 4.66 & 4.75 \\
Gross energy, kcal kg $^{-1}$ & $4,740.0$ & $4,584.0$ & $4,704.0$ & $4,765.0$ & $4,812.0$ & $4,943.0$ & $4,827.0$ & $4,474.0$ & $4,754.0$ & $4,775.0$ \\
\hline Composition & FA 0.10 & FA 0.12 & FS 1.0 & FS 2.0 & FS 3.0 & FS 4.0 & FS 5.0 & FS 6.0 & PC 10FP NC 100PV \\
\hline Protein, \% & 37.29 & 39.29 & 37.75 & 40.39 & 40.55 & 40.23 & 38.39 & 40.07 & 40.68 & 39.33 \\
Lipid, \% & 9.93 & 9.76 & 10.20 & 9.25 & 10.39 & 10.01 & 9.79 & 10.15 & 9.76 & 9.61 \\
Ash, \% & 5.35 & 5.51 & 6.05 & 6.39 & 5.99 & 6.24 & 6.38 & 5.49 & 6.41 & 5.40 \\
Crude fiber, \% & 4.44 & 4.36 & 4.59 & 4.38 & 4.53 & 4.46 & 4.21 & 4.05 & 4.59 & 3.98 \\
Gross energy, kcal kg & $4,778.0$ & $4,722.0$ & $4,917.0$ & $4,732.0$ & $4,946.0$ & $4,781.0$ & $4,813.0$ & $4,824.0$ & $4,654.0$ & $4,915.0$ \\
\hline
\end{tabular}

Table 4 - Initial weight (IW), weight (FW), weight gain (WG), feed intake (FI), feed conversion ratio (FCR) of juvenile largemouth bass fed plant protein-based diets containing different types and levels of attractants.

\begin{tabular}{lccrrrrrrrr}
\hline \multirow{2}{*}{ Performance } & \multicolumn{10}{c}{ Diet } \\
\cline { 2 - 11 } & SFP 0.5 & SFP 1.0 & SFP 1.5 & SFP 2.0 & SFP 2.5 & SFP 3.0 & FA 0.02 & FA 0.04 & FA 0.06 & FA 0.08 \\
\hline IW, g & 392.05 & 392.38 & 395.74 & 396.18 & 419.30 & 390.77 & 420.53 & 389.91 & 418.18 & 394.89 \\
FW, g & 410.09 & 409.80 & 416.54 & 409.65 & 433.38 & 409.99 & 465.21 & 419.03 & 437.90 & 426.99 \\
WG, g & 18.03 & 17.42 & 20.80 & 13.47 & 14.08 & 19.21 & 44.68 & 29.12 & 19.72 & 32.11 \\
FI, g & 46.33 & 45.03 & 50.57 & 49.15 & 44.62 & 47.40 & 52.53 & 45.05 & 50.44 & 50.43 \\
FCR, g & 2.61 & 2.75 & 2.49 & 5.79 & 5.30 & 2.72 & 1.35 & 1.67 & 4.55 & 1.64 \\
\hline Performance & FA 0.10 & FA 0.12 & FS1.0 & FS 2.0 & FS 3.0 & \multicolumn{1}{c}{ FS 4.0 } & FS 5.0 & FS 6.0 & PC 10FP NC 100PV \\
\hline IW, g & 370.99 & 398.77 & 409.52 & 401.58 & 405.89 & 392.16 & 398.53 & 378.64 & 387.49 & 409.59 \\
FW, g & 400.59 & 412.04 & 430.71 & 429.28 & 420.19 & 412.82 & 414.30 & 398.43 & 404.59 & 429.70 \\
WG, g & 29.60 & 13.28 & 21.19 & 27.70 & 14.30 & 20.67 & 15.77 & 19.79 & 17.10 & 20.11 \\
FI, g & 48.32 & 47.07 & 48.11 & 49.15 & 45.42 & 47.55 & 45.69 & 46.23 & 46.16 & 45.77 \\
FCR, g & 1.64 & 3.81 & 2.33 & 1.85 & 3.64 & 3.79 & 2.16 & 2.97 & 3.00 & 4.76 \\
\hline
\end{tabular}

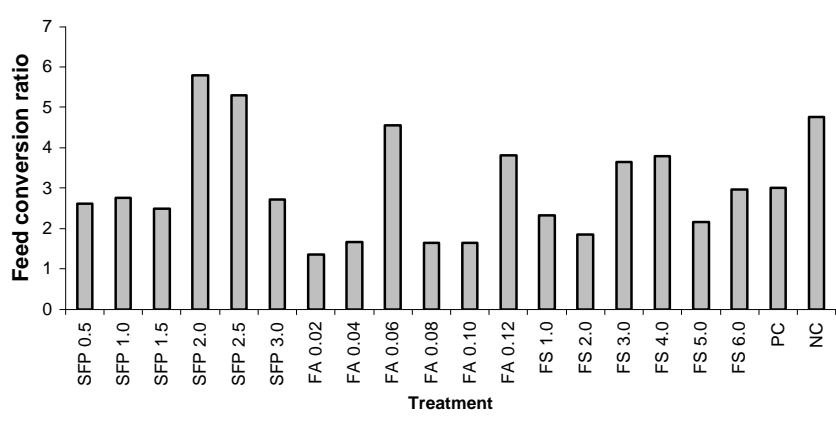

Figure 1 - Feed conversion ratio of juvenile largemouth bass fed diets containing different sources and levels of attractants.

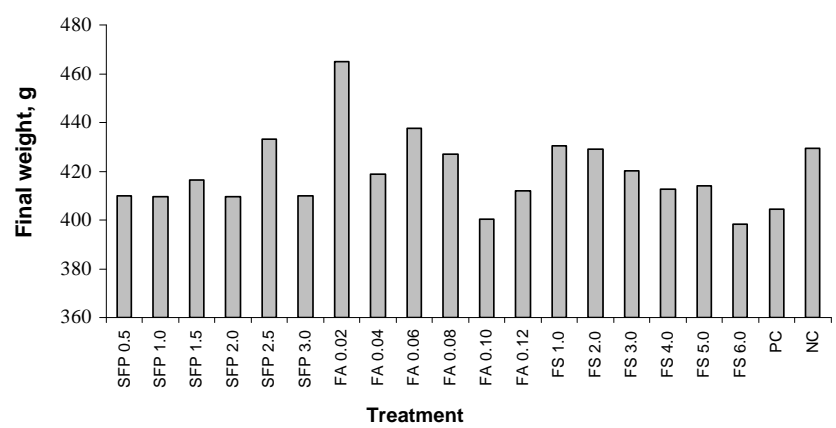

Figure 2 - Final weight of juvenile largemouth bass fed diets containing different sources and levels of attractants.

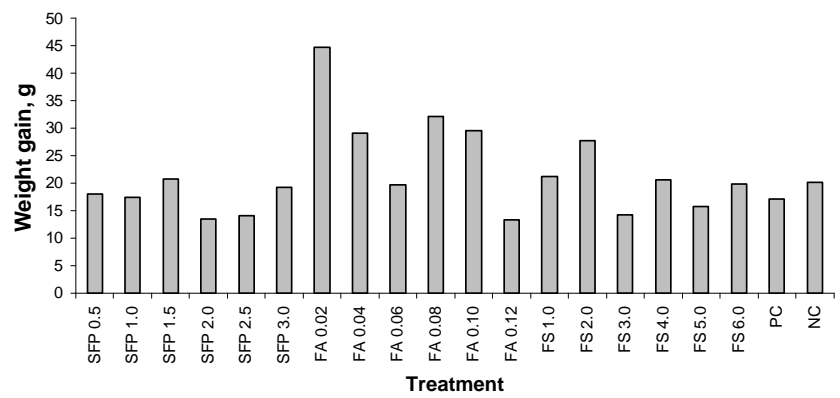

Figure 3 - Weight gain of juvenile largemouth bass fed diets containing different sources and levels of attractants.

Feed attractants may lose their stimulatory effect over time. Therefore, studies of feed attractants are performed over short intervals (Papatryphon \& Soares Jr., 2000b). Nonetheless, to mimic commercial fish farming conditions, it may be necessary to run feed attractant assays over extended periods. On the other hand, Papatryphon \& Soares Jr. (2000b) also emphasize that the economic viability of the use of feed attractants is still questionable. However, ecological considerations may require that substitution of fish meal by plant protein becomes a mandatory practice in fish diets in the near future, and using feed attractants in fish feeds may become necessary. 
Papatryphon \& Soares Jr. (2000a) reported that non-essential, neutral amino acids (alanine, serine, glycine and proline) are the more efficient feed attractants for the striped bass, Morone saxatilis. Supplementing 2\% fish solubles in the diet resulted in a significant increase in feed intake among striped bass, very close to the effects of the non-essential, neutral amino acids. However, supplementation of $2 \%$ FSP in fish meal-based diets for the red drum, Sciaenops ocellatus, did not positively affect growth (Davis et al., 1995), but $2 \%$ or $4 \%$ supplementation of FSP in soybean meal-based diets, increased feed intake and performance of the red drum (McGoogan \& Gatlin, 1997).

Hydrolyzed fish protein or fish hydrolysate (HFP), a non-conventional feedstuff used as protein supplement and feed stimulant, led to increased growth rate and food utilization in salmonids (Berge \& Storebakken, 1996; Carvalho et al., 1997). This positive effect can be attributed to increased digestibility of the HFP's protein resulting from enzymatic treatment of the raw material. Protein degradation yields short-chain peptides and free amino acids. As considered before, free amino acids work as feed stimulants for some fish species, increasing growth rate and feed use.

Oliva-Teles et al. (1999) found that the inclusion of fish hydrolysate as a substitute for fish meal (5, 15 and 25\%) did not improve performance of juvenile turbot Scophthalmus maximus. Enzymes involved in production of fish hydrolysate influence digestion in fish (Cahu et al., 1999). Secretion of trypsin was larger in fish fed diets without and with 19\% HFP, than in fish fed diets containing 38\% and 58\% HFP. Larger levels of HFP in the diet might have produced an excess of nutrients - amino acids and peptides in the intestine inducing saturation of the mechanisms of transport of nutrients, which could explain, in part, the negative effects of the high level of HFP in the diets. In the present study, the dietary levels of HSP were much lower -0.5 to $3.0 \%$.

Kubitza (1995) fed largemouth bass with soybean meal-based diets (60\% soybean meal) containing a mixture of amino acids (alanine $2,000 \mathrm{mg} \mathrm{kg}^{-1}$, glycine $3,836 \mathrm{mg} \mathrm{kg}^{-1}$, proline $305 \mathrm{mg} \mathrm{kg}^{-1}$, serine $1.205 \mathrm{mg} \mathrm{kg}^{-1}$, leucine $614 \mathrm{mg} \mathrm{kg}^{-1}$, valine $800 \mathrm{mg} \mathrm{kg}^{-1}$, histidine $273 \mathrm{mg} \mathrm{kg}^{-1}$, and tryptophan $318 \mathrm{mg} \mathrm{kg}^{-1}$ ), nucleotides (inosine $2,800 \mathrm{mg} \mathrm{kg}^{-1}$ and inosine-5-monophosphate IMP-5' - 2,800 $\left.\mathrm{mg} \mathrm{kg}^{-1}\right)$, and betaine $\left(6,100 \mathrm{mg} \mathrm{kg}^{-1}\right)$, arranged as follows: amino acids only; betaine only; nucleotides only; amino acids + betaine; amino acids + nucleotides; betaine + nucleotides; and amino acids + betaine + nucleotides. Daily feed consumption of diets containing attractants, versus the original diet and growth performance of fish were recorded. Fish fed diets containing only nucleotides presented better performance. Contrary to initial expectations, Kubitza (1995) observed that betaine, abundant in extracts of crustaceans and considered a good stimulant of feed consumption by fish, was not effective for largemouth bass. The IMP-5', abundant in fish muscles and, consequently, in fish meal, presented the best stimulatory effect on feed consumption.

Some substances present in fish meal probably work as feed stimulants (Xue \& Cui, 2001). According to Kubitza (1995), inosine-5-monophosphate (IMP-5'), which is abundant in fish muscle and consequently in fish meal, was the substance that presented better attractant effect in feed intake for largemouth bass. In this work, fish meal had little or no stimulatory effect in diets containing meat and bone meal, which may have exerted some harmful, stale effect in the diets, leading fish to reject feed even when attractants were added. Considering that no differences were detected among treatments, there is no evidence that any of the attractants had an effect. Therefore, none of them should be recommended.

\section{ACKNOWLEDGMENTS}

To Fundação de Amparo à Pesquisa do Estado de São Paulo (FAPESP) for the scholarship granted to the first author (99-00412-8).

\section{REFERENCES}

ADAMS, M.A.; JOHNSEN, P.B.; ZHOU, H-qi. Chemical enhancement of feeding for the herbivorous fish Tilapia zillii. Aquaculture, v.72, p.95107, 1988.

BERGE, G.M.; STOREBAKKEN, T. Fish protein hydrolyzate in starter diets for Atlantic salmon (Salmo salar) fry. Aquaculture, v.145, p.205212,1996

BRUNE, D.E.; TOMASSO, J.R. Aquaculture and water quality. Baton Rouge: The World Aquaculture Society, 1991. 606p.

CAHU, C.L.; INFANTE, Z.; QUAZUGUEL, P.; LE GALL, M.M. Protein hydrolysate vs. fish meal in compound diets for 10-day old sea bass Dicentrarchus labrax larvae. Aquaculture, v.171, p.109-119, 1999.

CARVALHO, A.P.; ESCAFFRE, A.M.; OLIVA-TELES, A.; BERGOT, P. First feeding of common carp larvae on diets with high levels of protein hydrolysates. Aquaculture International, v.5, p.361-367, 1997.

CYRINO, J.E.P; KUBITZA, F. Diets for feed training peacock bass Cichla sp. Scientia Agricola, v.60, p.609-613, 2003.

DAVIS, D.A.; JIRSA, D.; ARNOLD, C.R. Evaluation of soybean proteins as replacements for menhaden fish meal in practical diets for red drum (Sciaenops ocellatus). Journal of the World Aquaculture Society, v.26, p.48-58, 1995.

FAO. The state of world fisheries and aquaculture 2002. Rome, 2002. $150 \mathrm{p}$.

GODOY, M.P. Observações sobre a adaptação do "black bass" (Micropterus salmoides) em Pirassununga, Estado de São Paulo. Revista Brasileira de Biologia, v.14, p.32-38, 1954.

HUGHES, S.G. Response of first-feeding spring Chinook Salmon to four potential chemical modifiers of feed intake. The Progressive Fish Culturist, v.53, p.17-20, 1991.

KUBITZA, F. Preparo de rações e estratégias de alimentação no cultivo intensivo de peixes carnívoros. In: SIMPÓSIO INTERNACIONAL SOBRE NUTRIÇÃO DE PEIXES E CRUSTÁCEOS, Campos do Jordão, 1995. Anais. Campos do Jordão: CBNA, 1995. p.91-115. 
KUBITZA, F.; LOVSHIN, L.L. Pond production of pellet-fed advanced juvenile and food-size largemouth bass. Aquaculture, v.149, p.253262, 1997.

McGOOGAN, B.B.; GATLIN, D.M. Effects of replacing fish meal with soybean meal in diets for red drum Sciaenops ocellatus and potential for palatability enhancement. Journal of the World Aquaculture Society, v.28, p.374-385, 1997.

OLIVA TELES, A.; CERQUEIRA, A.L; GONÇALVES, P. The utilization of diets containing high levels os fish hydrolysate by turbot (Scophthalmus maximus) juveniles. Aquaculture, v.179, p.195-201, 1999.

PAPATRYPHON, E.; SOARES JR., J.H. Identification of feeding stimulants for striped bass, Morone saxatilis. Aquaculture, v.185, p.339-352, 2000a.
PAPATRYPHON, E.; SOARES JR., J.H. The effect of dietary stimulants on growth performance of striped bass, Morone saxatilis, fed-a-plant feedstuff-based diet. Aquaculture, v.185, p.329-338, 2000b.

XUE, M.; CUI, Y. Effect of several feeding stimulants on diet preference by juvenile gibel carp (Carassius auratus gibelio), fed diets with or without partial replacement of fish meal by meat and bone meal Aquaculture, v.198, p.281-292, 2001.

Received May 27, 2003

Accepted February 16, 2004 